\title{
PEMBUATAN KOMPOSIT BATA MERAHDARI LIMBAH PADAT PABRIK MINYAK NABATI
}

\author{
MAKING OF RED BRICK COMPOSITE FROM SOLID WASTE OF COCONUT OIL \\ FACTORY
}

\author{
A. Luther Ola \\ Baristand Industri Manado \\ Jalan Diponegoro No.21-23 Manado \\ email: ola.luther@yahoo.co.id \\ Diterima tgl 25-05-2015, Disetujui tgl 01-06-2015
}

\begin{abstract}
ABSTRAK
Pengembangan teknologi proses bata merah limbah padat pabrik minyak nabati, yaitu spent bleaching earth telah dilakukan. Tujuan penelitian adalah untuk mengkaji pemanfaatan limbah pabrik minyak nabati sebagai bahan baku pembuatan bata merah yang sekiranya dapat berperan untuk mengatasi masalah lingkungan dari limbah padat yang menumpuk di lokasi pabrik minyak nabati. Penelitian dilaksanakan dalam dua tahap yakni, penelitian pendahuluan untuk mendapatkan komposisi bahan yang baik dan penelitian lanjutan yaitu pembuatan bata merah skala teknis produksi. Hasil penelitian pendahuluan menunjukkan bahwa bata percobaan untuk perlakuan bahan $A_{1}-F_{1}$ memiliki karakteristik sedikit plastis $\mathrm{s} / \mathrm{d}$ agak plastis, tidak retak dan tidak bengkok saat dikeringkan, dengan susut kering antara $7,5-7,79 \%$, selanjutnya tidak retak dan tidak bengkok setelah dibakar pada suhu $\pm 700{ }^{\circ} \mathrm{C}$ dengan susut bakar antara $1,92-2,94 \%$. Berdasarkan hasil penelitian pendahuluan tersebut selanjutnya dilakukan pencetakan bata merah skala teknis produksi dengan perlakuan (komposisi campuran bahan) (B): 60 bagian SBE+25 bagian Tanah Liat (TL)+15 bagian Domato; $(\mathrm{C})$ : 50 bagian SBE+25 bagian TL+25 bagian Domato; dan (D): 70 bagian SBE+20 bagian $\mathrm{TL}+10$ bagian Domato. Hasil uji fisik kuat tekan bata merah dari limbah padat pabrik minyak nabati menunjukkan bahwa semua perlakuan memenuhi persyaratan. Produk dengan kuat tekan kelas terendah terdapat pada perlakuan (B), yakni $63,30 \mathrm{~kg} / \mathrm{cm}^{2}$ dan yang tertinggi pada perlakuan (C), yakni 103,30 $\mathrm{kg} / \mathrm{cm}^{2}$. Bila ditinjau dari semua parameter uji maka produk bata merah perlakuan D memenuhi syarat SNI 152094-2000 dengan kuat tekan pada kelas $100 \mathrm{~kg} / \mathrm{cm}^{2}$.
\end{abstract}

Kata kunci: Spent bleaching earth, tanah domato, tanah liat, bata merah.

\section{ABSTRACT}

Research on utilizing spent bleaching earth (SBE) produced by vegetable oil factory in BitungCity has been done. The research objective was to assess the use of SBE as raw material for red brick making aiming to minimize environmental problems of accumulated solid waste at the plant complex. The research was conducted in two phases, i.e. preliminary research to get good material composition and further research to conduct a technical scale production of red brick. Preliminary research indicated that treatments $A_{1}-F_{1}$ have characteristics of little loamy to rather loamy, not crack and bent when dried, with dry shrinkage of 7.5 to $7.79 \%$, not crack and bent after being burned at a temperature of $\pm 700{ }^{\circ} \mathrm{C}$, with burning shrinkage of between 1.92 to $2.94 \%$. Based on preliminary results, the making of red bricks are then continued to technical scale limited to three best treatments, i.e. (B): 60 parts of SBE+25 parts of clay (TL)+15 parts of "domato"; (C): 50 parts SBE+25 parts of $T L+25$ parts of domato; and $(D): 70$ parts of $S B E+20$ parts of $T L+10$ parts of domato. All the three treatments produced red bricks having physical testing of compressive strength that meet all requirements. Treatment that produced the lowest compressive strength which is $63.30 \mathrm{~kg} / \mathrm{cm}^{2}$ was $B$, whilsttreatment produced the highest compressive strength was $(C)$, which is $103.30 \mathrm{~kg} / \mathrm{cm}^{2}$. Viewed from all test parameters, treatment D qualify SNI 15-2094-2000 with compressive strength at a grade of $100 \mathrm{~kg} / \mathrm{cm}^{2}$.

Keywords: spent bleaching earth, domato soil, clay, red brick

\section{PENDAHULUAN}

\section{Latar Belakang}

Untuk mendapatkan minyak nabati yang berkualitas dapat melalui beberapa tahapan proses yaitu bleaching, fraksionasi, deodorasi dan lain-lain. Semakin tinggi tingkat prosesnya, semakin baik kualitas minyak yang dihasilkan ${ }^{1}$. Proses pengolahan bahan baku baik CCO maupun CPO 
dilakukan dengan cara pemisahan bahan untuk menghilangkan partikel-partikel halus yang tersuspensi atau berbentuk koloid ${ }^{2}$. Netralisasi dilakukan untuk memisahkan senyawa-senyawa terlarut seperti kostitatida dan asam lemak bebas, sedangkan pemucatan atau bleach dilakukan untuk menghilangkan zat warna dalam minyak dengan penambahan absorben seperti arang aktif dan bentonit atau bleaching earth ${ }^{3}$.

Bleaching earth merupakan bahan pemucat yang terdiri dari sejenis tanah liat dengan komposisi utama Silikat dan Aluminium oksida, air terikat, Kalsium, Magnesium dan Besi oksida. Dalam proses ini zat warna dalam minyak akan diserap oleh permukaan absorben dan juga menyerap koloid seperti gun dan resin hasil degradasi dari minyak. Khusus untuk pemucatan minyak kelapa sawit atau CPO hanya menggunakan bleaching earth diantaranya bentonit atau activated clay yang menghasilkan limbah padat disebut spent bleaching earth (SBE) dengan singkatan atau bahasa di pabrik Spent bleaching earth. Pada proses bleaching di pabrik minyak kelapa sawit umumnya menggunakan Bentonit sekitar 2,5\% dari bobot/berat $\mathrm{CPO}^{4}$. Dengan demikian limbah padat (Spent bleaching earth) dari proses pemucatan tersebut cukup banyak. Limbah padat ini cukup menimbulkan masalah disekitar parbik karena memerlukan tempat penimbunan tersendiri. Limbah padat ini dengan bahan dasar bentonit merupakan lempung atau tanah liat yang sama digunakan sebagai bahan baku keramik termasuk di dalamnya untuk pembuatan bata merah sebagai bahan bangunan.
Bata merah dibuat dari tanah liat yang memiliki sifat-sifat kimia dan fisik yang sangat penting antara lain keplastisan, kekuatan kering, susut kering dan susut bakar.

Keplastisan adalah sifat lempung yang memungkinkan lempung tersebut dapat berubah bentuk selama bekerjanya suatu gaya dari luar dan apabila gaya dari luar tersebut berhenti, maka perubahan bentuknya juga tidak berhenti dan bentuk terakhir tetap dan tidak kembali kebentuk semula. Sifat keplastisan dari tanah liat setelah diberi air pembentuk yang optimum dapat diketahui tingkat keplastisannya yakni bersifat plastis, agak plastis, sedikit plastis atau bahan tanah tersebut bersifat tidak plastis. Bahan tanah untuk dapat dibuat produk bata merah harus mempunyai sifat maksimal agak plastis dan minimal sedikit plastis.Jika bahan yang ada bersifat tidak plastis harus ditambahkan bahan tanah yang bersifat plastis, sebaliknya apabila bahan yang ada dalam keadaan plastis harus ditambahkan bahan pengurus seperti tanah berpasir seperti tanah domato, kulit tanah dan lain-lain ${ }^{5}$.

Kekuatan kering dari bahan baku tanah untuk bata merah adalah suatu sifat yang timbul dari bahan setelah dibentuk atau dicetak menjadi produk mempunyai kekuatan setelah dikeringkan. Sifat ini sangat penting dalam industri bata merah, karena dengan adanya sifat ini maka bata-merah dapat mampu menyangga bahannya sendiri, memungkinkan untuk dapat dipidahpindahkan terutama dalam pengeringan dengan penjemuran pada sinar matahari dan penyusunan dalam tungku pembakaran. 
Sifat-sifat lainnya yang tidak kalah penting dari bahan untuk produk bata merah adalah susut kering dan susut bakar. Susut kering tidak boleh lebih dari 10\% sebab jika terlalu besar akan menyebabkan terjadinya perubahan bentuk saat pengeringan misalnya bengkok/melengkung ataupun retak-retak ${ }^{6}$. Susut bakar tidak boleh lebih dari $3 \%$, sebab jika terlalu besar akan menyebabkan terjadinya perubahan bentuk, cacat, pecah-pecah/retak setelah melalui pembakaran.

Limbah padat Spent bleaching earth dari pabrik minyak nabati memiliki sifat yang tidak plastis dan sedikit mengandung minyak sekitar $18 \%{ }^{7}$. Untuk dapat dibentuk menjadi produk bata merah maka perlu ditambahkan bahan yang bersifat plastis.

Penelitian ini bertujuan untuk mengkaji komposit bata merah yang menggunakan limbah padat spent bleaching earth dari pabrik minyak nabati. Dengan demikian nantinya diharapkan akan tumbuh indutri kecil bata merah yang menggunakan bahan limbah spent bleaching earth dari pabrik minyak nabati, sehingga dapat mengurangi dampak lingkungan disekitar lokasi pabrik dan penduduk sekitarnya.

\section{Batasan Kegiatan}

Penelitian pendahuluan dilakukan untuk mendapatkan komposisi bahan melalui pengamatan dan pengujian fisik benda coba, melakukan pencetakan pembuatan produk bata merah dan uji mutu bata merah berdasarkan SNI yang ada ${ }^{8}$.

\section{BAHAN DAN METODE}

\section{Bahan dan Alat}

Bahan yang digunakan dalam penelitian ini yaitu limbah padat SBE, tanah liat plastis dan tanah domato. Sedangkan peralatan yang digunakan yaitu loyang plastik besar, ember, sendok semen, sekop, ayakan kawat kasah, alat cetak bata, tungku pembakaran, peralatan laboratorium lainnya seperti tanur listrik, timbangan digital, oven dII.

\section{Metode Penelitian}

1. Penelitian pendahuluan.

Dilakukan untuk mendapatkan komposisi campuran bahan limbah padat, tanah liat dan tanah domato.

Variasi Campuran Bahan pada Penelitian. Pendahuluan dapat dilihat pada Tabel.1sebagaiberikut.

Tabel 1. Variasi Campuran Bahan Baku untuk Bata Percobaan

\begin{tabular}{lcccccc}
\hline \multicolumn{1}{c}{ Bahan/Kode } & A & B & C & D & E & F \\
\hline SBE (b/b) & 70 & 60 & 50 & 70 & 60 & 50 \\
Tanah Liat (b/b) & 25 & 25 & 25 & 20 & 20 & 20 \\
"Domato" (b/b) & 5 & 15 & 25 & 10 & 20 & 30 \\
\hline
\end{tabular}

Penelitian dilakukan dengan membuat bata percobaan dengan ukuran $12 \times 6 \times 2 \mathrm{~cm}$, dikeringkan lalu dibakar pada tanur listrik dengan temperature $600^{\circ} \mathrm{C}$. Bata percobaan ini diamati pada keadaan kering dan keadaan setelah dibakar diukur susut keringnya, susut bakar dan susut jumlah.Penelitian dilakukan dengan ulangan 2 kali. 
2. Penelitian lanjutan terhadap perlakuan terbaik pada penelitian pendahuluan

- Pencetakan bata secara teknis produksi menggunakan alat cetak semi mekanis, ukuran: $20 \times 15 \times 5 \mathrm{~cm}$.

- Dikeringkan dan dibakar pada tungku skala produksi.

- Dianalisis merujuk pada SNI 15-20942000 tentang mutu dan cara uji bata merah.

3. Tahapan pembuatan bata merah dari limbah padat SBE

- Persiapan Bahan

- Disiapkan limbah padat SBE dari pabrik minyak nabati.

- Tanah liat dan tanah domato dikeringkan lalu diayak dengan ayakan kawat kasah diameter 2-3 mm.

- Pembuatan Adonan

Tanah liat dan tanah domato ditambahkan kedalam limbah SBE yang telah diukur sesuai perlakuan lalu diulek atau diaduk hingga merata (dapat digunakan alat pencampur mekanik).

Dalam pembuatan adonan siap cetak digunakan air secukupnya hingga bahan dalam keadaan agak plastis.Selanjutnya dibiarkan selama 1-2 hari untuk pemerataan air pembentuk.

\section{- Pencetakan Produk}

Adonan yang telah diperam semalam atau lebih dicetak dalam bentuk bata merah dengan ukuran sesuai standar, dibiarkan selama 2-3 hari dalam ruangan tertutup.

\section{- Pengeringan}

Bata yang telah dicetak dan sudah kuat dikeringkan dipinggir ruangan dengan posisi miring dan disusun 2-3 bata atau produk.Pengeringan dilanjutkan pada sinar matahari selama kurang lebih 2 minggu.

- Pembakaran

Bata yang sudah kering disusun kedalam tungku lalu dibakar yang dimulai dengan pada suhu rendah sampai suhu tinggi atau pembakaran optimal ${ }^{9}$.

- Pendinginan

Setelah pembakaran selesai api dibiarkan padam dan dibiarkan semalam, selanjutnya bata merah dibongkar atau dikeluarkan dari tungku secara bertahap.

\section{Pengamatan}

Produk bata merah yang dihasilkan diuji berdasarkan SNI 15-2094-2000. Data yang diperoleh diuji dengan metode deskriptif.

\section{HASIL DAN PEMBAHASAN}

\section{Limbah Padat Pabrik Minyak Nabati}

Salah satu limbah padat cukup potensil pada pabrik nabati adalah Spent bleaching earth. Limbah padat ini diperoleh dari proses Bleach CPO dan CNO menggunakan bentonit, arang aktif dan lain-lain. Khususnya pengolahan CPO tidak menggunakan arang aktif, tetapi hanya menggunakan bentonit dan sedikit asam fosfor.Hasil analisis kimia limbah padat/spent bleaching earth dapat dilihat pada

Tabel

2. 
Tabel 2. Hasil Analisis Kimia Limbah Padat (Spent bleaching earth)

\begin{tabular}{llcccc}
\hline \multirow{2}{*}{ No. } & \multicolumn{1}{c}{ Parameter } & I & II & Rata-rata & Ket. \\
\cline { 3 - 4 } & & $\mathbf{( \% )}$ & $\mathbf{( \% )}$ & \\
\hline 1 & Silikat (SiO2) & 58,4 & 59,41 & 58,90 \\
2 & Aluminium (Al2O3) & 11,3 & 9,85 & 10,29 \\
3 & Feroksida (Fe2O3) & 5,70 & 6,58 & 6,14 \\
4 & Magnesium (MgO) & 2,80 & 3,42 & 3,11 \\
5 & Calsium (CaO) & 3,25 & 3,13 & 3,19 \\
6 & Natrium (Na2O) & 0,68 & 0,10 & 0,14 \\
7 & Kalium (K2O) & 0,95 & 0,93 & 0,94 \\
8 & Kadar Minyak & 19,23 & 19,15 & 19,19 \\
9 & Kadar Air & 4,08 & 4,23 & 4,16 \\
\hline
\end{tabular}

\section{Hasil Penelitian Pendahuluan}

Hasil pengamatan dan uji bata percobaan dalam penelitian ini dapat dilihat pada Tabel 3.Dari hasil pengamatan campuran bahan (sesuai perlakuan pada Tabel2 diatas, dapat diketahui bahwa tingkat keplastisan terdapat pada kondisi sedikit plastis dan agak plastis. Hal ini berarti komposisi bahan (sesuai perlakuan) dapat dibentuk/dicetak menjadi bata merah ${ }^{10}$.Pada keadaan kering menunjukkan bahwa campuran bahan setelah kering udara (2-3 hari) cukup kuat diangkat/dipindahkan ketempat lain, tidak retak dan tidak melengkung/bengkok.

Tabel 3. Hasil Pengamatan Percobaan

\begin{tabular}{|c|c|c|c|c|c|c|c|}
\hline $\begin{array}{l}\text { Kode } \\
\text { Contoh }\end{array}$ & Keplastisan & $\begin{array}{c}\text { Keadaan } \\
\text { Kering }\end{array}$ & $\begin{array}{c}\text { Susut } \\
\text { Kering } \\
(\%)\end{array}$ & $\begin{array}{c}\text { Susut } \\
\text { Bakar } \\
(\%)\end{array}$ & $\begin{array}{c}\text { Rata-rata } \\
\text { Susut } \\
\text { Jumlah } \\
(\%)\end{array}$ & Warna & Keadaan \\
\hline$A$ & Agak plastis & $\begin{array}{c}\text { Kuat, tidak retak } \\
\text { dan tidak } \\
\text { melengkung }\end{array}$ & 7.5 & 2,94 & 10,4 & $\begin{array}{c}\text { Merah } \\
\text { mudah } \\
\text { sampai tua }\end{array}$ & $\begin{array}{l}\text { Retak } \\
\text { rambut, } \\
\text { tidak } \\
\text { bengkok }\end{array}$ \\
\hline B & Agak plastis & $\begin{array}{c}\text { Kuat, tidak retak } \\
\text { dan } \\
\text { tidak } \\
\text { melengkung }\end{array}$ & 7.67 & 2.13 & 9.79 & $\begin{array}{c}\text { Merah } \\
\text { mudah } \\
\text { sampai tua }\end{array}$ & $\begin{array}{l}\text { Retak } \\
\text { rambut, } \\
\text { tidak } \\
\text { bengkok }\end{array}$ \\
\hline $\mathrm{C}$ & Agak plastis & $\begin{array}{c}\text { Kuat, tidak retak } \\
\text { dan } \\
\text { tidak } \\
\text { melengkung }\end{array}$ & 7.74 & 2.02 & 9.76 & $\begin{array}{c}\text { Merah } \\
\text { mudah } \\
\text { sampai tua }\end{array}$ & $\begin{array}{l}\text { Retak } \\
\text { rambut, } \\
\text { tidak } \\
\text { bengkok }\end{array}$ \\
\hline D & $\begin{array}{l}\text { Sedikit } \\
\text { plastis }\end{array}$ & $\begin{array}{c}\text { Kuat, tidak retak } \\
\text { dan } \\
\text { tidak } \\
\text { melengkung }\end{array}$ & 7.5 & 2.37 & 9.92 & $\begin{array}{c}\text { Merah } \\
\text { mudah } \\
\text { sampai tua }\end{array}$ & $\begin{array}{l}\text { Retak } \\
\text { rambut, } \\
\text { tidak } \\
\text { bengkok }\end{array}$ \\
\hline$E$ & $\begin{array}{l}\text { Sedikit } \\
\text { plastis }\end{array}$ & $\begin{array}{c}\text { Kuat, tidak retak } \\
\text { dan } \\
\text { tidak } \\
\text { melengkung }\end{array}$ & 7.79 & 2.82 & 10.6 & $\begin{array}{c}\text { Merah } \\
\text { mudah } \\
\text { sampai tua }\end{array}$ & $\begin{array}{c}\text { Retak } \\
\text { rambut, } \\
\text { tidak } \\
\text { bengkok }\end{array}$ \\
\hline$F$ & $\begin{array}{l}\text { Sedikit } \\
\text { plastis }\end{array}$ & $\begin{array}{c}\text { Kuat, tidak retak } \\
\text { dan } \\
\text { tidak } \\
\text { melengkung }\end{array}$ & 7.72 & 2.76 & 10.44 & $\begin{array}{c}\text { Merah } \\
\text { mudah } \\
\text { sampai tua }\end{array}$ & $\begin{array}{l}\text { Retak } \\
\text { rambut, } \\
\text { tidak } \\
\text { bengkok }\end{array}$ \\
\hline
\end{tabular}


Pada perhitungan susut kering ternyata terdapat pada kisaran $7,5-7,79 \%$,susut bakar pada kisaran 1,92-2,94\% dengan susut jumlah pada kisaran 9,76-10,60.Susut kering yang terlalu rendah atau kecil memudahkan bahan yang digunakan tidak plastis, sehingga mengurangi kekuatan dari produk bata karena daya rekatnya rendah, sebaiknya bila surut kering dan surut bakarnya tidak terlalu tinggi akan menyebabkan produk setelah dikeringkan atau dibakar akan retak-retak. Susut kering sebaiknya tidak lebih dari $10 \%$ dan susut bakar tidak lebih dari 3 atau susut jumlah maksimum $12 \%$. Keadaan setelah dibakar agak retak rambut tapi tidak bengkok atau melengkung dengan warna merah mudah bercampur hitam.Dengan memperhatikan susut jumlah pada Tabel 3, perlakuan terbaik adalah susut jumlah dengan kode perlakuan contoh B, C dan D. karena dibawa $10 \%$.Berdasarkan hasil pengamatan penelitian pendahuluan tersebut, maka penelitian dilanjutkan pada pencetakan bata merah skala teknis pada campuran/komposisi bahan berikut ini:

Tabel 4. Komposisi bahan bata merah dari limbah padat pabrik minyak nabati

\begin{tabular}{cccc}
\hline Bahan & B & C & D \\
\hline SBE & 60 & 50 & 70 \\
Tanah liat & 25 & 25 & 20 \\
Domato & 15 & 25 & 10 \\
\hline
\end{tabular}

Ulangan 2 (dua) kali

\section{Penelitian Lanjutan}

Penelitian lanjutan dilaksanakan dengan membuat bata merah skala teknis berdasarkan ukuran Modul M-6b yaitu Tebal $=55 \mathrm{~mm}$, Lebar=110 mm dan Panjang $230 \quad \mathrm{~mm}$. Secara keseluruhandalamtahapan/proses pembuatan bata mulai daripencampuran/penguletan bahan, pencetakan, pengeringan sampai pada pembakaran dilakukan bekerjasama denganpengusaha pembuat bata merah pada sentra industri kecil bata merah di Kelurahan Taas dan Liwas Kota Manado. Produk bata merah yang dihasilkan, diuji mutunya berdasarkan SNI. 15-2094-2000.

Tabel 5. Hasil Uji Mutu Bata Merah dari Limbah Padat Pabrik Minyak Nabati

\begin{tabular}{|c|c|c|c|c|c|c|c|c|c|}
\hline \multirow{2}{*}{$\begin{array}{l}\text { Kode } \\
\text { Contoh }\end{array}$} & \multirow[t]{2}{*}{ Tampak Luar } & \multicolumn{3}{|c|}{ Ukuran, mm } & \multicolumn{3}{|c|}{$\begin{array}{l}\text { Penyimpa } \\
\text { ngan Uk }\end{array}$} & \multirow{2}{*}{$\begin{array}{c}\text { Kuat } \\
\text { Tekan } \\
\text { kg/cm² }\end{array}$} & \multirow{2}{*}{$\begin{array}{l}\text { Kadar } \\
\text { Garam }\end{array}$} \\
\hline & & $\mathbf{T}$ & $\mathbf{L}$ & $\mathbf{P}$ & $\mathrm{T}$ & $\mathbf{L}$ & $\mathbf{P}$ & & \\
\hline B1 & $\begin{array}{l}\text { Bentuk prisma, rusuk siku } \\
\text { dan tajam, rata sedikit retak }\end{array}$ & 54 & 109 & 223 & 1 & 1 & 7 & 63,3 & $\begin{array}{l}\text { Tidak ada } \\
\text { pengkristalan }\end{array}$ \\
\hline B2 & $\begin{array}{l}\text { Bentuk prisma, siku } \\
\text { tajam, rata tidak retak }\end{array}$ & 55 & 109 & 225 & 0 & 1 & 5 & 73.30 & $\begin{array}{l}\text { Tidak ada } \\
\text { pengkristalan }\end{array}$ \\
\hline C1 & $\begin{array}{l}\text { Bentuk prisma, siku, tajam } \\
\text { rata sedikit retak }\end{array}$ & 54 & 110 & 221 & 1 & 0 & 9 & 99,3 & $\begin{array}{l}\text { Tidak ada } \\
\text { pengkristalan }\end{array}$ \\
\hline $\mathrm{C} 2$ & $\begin{array}{l}\text { Bentuk prisma, siku, tajam } \\
\text { rata sedikit retak }\end{array}$ & 54 & 110 & 223 & 1 & 0 & 7 & 103,3 & $\begin{array}{l}\text { Tidak ada } \\
\text { pengkristalan }\end{array}$ \\
\hline D1 & $\begin{array}{l}\text { Prisma, siku, tajam, rata dan } \\
\text { tidak retak }\end{array}$ & 55 & 109 & 226 & 0 & 1 & 4 & 80 & $\begin{array}{l}\text { Tidak ada } \\
\text { pengkristalan }\end{array}$ \\
\hline $\mathrm{D} 2$ & $\begin{array}{l}\text { Prisma, siku, tajam, rata dan } \\
\text { tidak retak }\end{array}$ & 55 & 110 & 225 & 0 & 0 & 5 & 90 & $\begin{array}{l}\text { Tidak ada } \\
\text { pengkristalan }\end{array}$ \\
\hline $\mathrm{X} 1$ & Prisma, siku, tajam, rata dan & 50 & 100 & 200 & 4 & 3 & 2 & 120 & Tidak ada \\
\hline
\end{tabular}




\begin{tabular}{llllllllll}
\hline X2 & $\begin{array}{l}\text { tidak retak } \\
\text { Prisma, siku, tajam, rata dan } \\
\text { tidak retak }\end{array}$ & 50 & 100 & 2500 & 4 & 3 & 2 & 117,5 & $\begin{array}{l}\text { pengkristalan } \\
\text { Tidak ada } \\
\text { pengkristalan }\end{array}$ \\
\hline
\end{tabular}

1. Tampak Luar

Dari hasil pengamatan tampak luar pada Tabel 5, dapat dilihat bahwa produk bata merah dari limbah padat pabrik minyak nabati padamasing-masing perlakuan campuran bahan dihasilkan bata merah dalam bentuk prisma segi empat panjang denganrusuk-rusuk yang siku dan tajam dan bidang datarnya rata, namun terdapatsebagian kecil retak-retak kecuali contoh dengan campuran bahan pada Kode $D$ tidak retak.

Adanya keretakan pada bidang datar dari beberapa contoh diduga terjadi pada pembakaran akibat kejutan panas yang tinggi dan bata tersebut terlalu dekatdengan sumber nyala api mengakibatkan sebagian bidang datar bata kelewat bakar.Dibandingkan dengan Standar Nasional Indonesia SNI 15-2094-2000, komposisicampuran bahan padaKode $\mathrm{D}$ memenuhisyarat untuk tampak luar.Mal ukuran yang disiapkan didasarkan pada susut jumlah hasil

2. Ukuran

Ukuran bata merah dalam penelitian ini ditentukan berdasarkan standar yang ada yakni M-6b dengan dimensi Tebal $=55 \mathrm{~mm}$, Lebar $=110 \mathrm{~mm}$ dan Panjang=230 $\mathrm{mm}$.

Dari hasil pengamatan dan pengukuran produk bata merah yang dihasilkan dalam penelitian ini ternyata untuk ukuran tebal dan lebar memenuhi syarat.Hal ini dapat dilihat pada nilai penyimpangan ukuran masih dibawah persyaratan penyimpangan ukuranmaksimum (Tebal maks $2 \mathrm{~mm}$ danLebar maks 2-3 mm).
Penyimpangan ukuran panjang tertinggi terdapat pada Kode contoh B dan C. Terjadinya penyusutan ukuran panjang disebabkan oleh penyusutan dalam pembakaran. Ditinjau dari faktor ukuran dan penyimpangan ukuran maksimum, produk bata merah dengan perlakuan 70SBE +20 TL dan 10 Tanah Domato (D)memenuhi standar yang ada.

3. Kuat Tekan

Hasil pengujian kuat tekan bata merah dari limbah pada pabrik minyak nabati menunjukkan bahwa dari semua contoh bata merah dari masing-masing perlakuan campuran bahan tidak yang memenuhi syarat. Kuat tekan terkecil terdapat pada contoh dengan Kode B1 $=63,30 \mathrm{~kg} / \mathrm{cm}^{2}$ dan yang tertinggi pada perlakuan bahan dengan Kode $\quad C 1=103,30 \quad \mathrm{~kg} / \mathrm{cm}^{2}$. Dibandingkan dengan kekuatan tekan bata merah dari pengusaha setempat, ternyata bata merah dari limbah padat pabrik minyak nabati hanya sedikit lebih rendah.

Rendahnya kuat tekan bata merah dari limbah padat pabrik minyak nabati ini dapat disebabkan oleh proses pengolahannya yang masih sederhana mulai dari pencampuranbahan sampai pada tahap pembakaran.

Pembakaran bata merah dari limbah padat pabrik minyak nabati ini sebaiknya dilakukan dengan api kecil dan kenaikan suhu diatur secara bertahap. Dengan adanya kandungan minyak dalam limbah tersebut, maka tahap awal pembakaran harus dilakukan waktu yangcukup lama hingga kandungan minyak tersebut habis terbakar. 
Salanjutnya pembakaran bata dilanjutkan dengan api penuh sampai selesai, namun untuk bata yang menggunakan sebagian besar limbah padat pabrik minyak nabati tidak bias dibakar pada suhu tinggi.

Hal ini diduga rendahnya kuat tekan dapat disebabkan suhu pembakaran yang cukup tinggi menyebabkan bahan limbah dengan partikel yang cukup halus berubah bentuk menjadi partikel debu yang melemahkan ikatannya dengan tanah liat sebagai pengikat (Glue).

4. Garam yang dapat larut dan membahayakan

Hasil pengamatan terhadap produk bata merah dari limbah padat pabrik minyak nabati menunjukkan bahwa tidak terdapat pengkristalan garam pada permukaan bata setelah dilakukan pengujian dengan perendaman dalam air.

\section{KESIMPULAN}

Limbah padat pabrik minyak nabati yang biasa disebut spent bleaching earth dapat dibuat menjadi bata merah pejal dengan bahan tambahan tanah liat plastis dan tanah domato dengan memanfaatkan SBE 50-70 $\%(b / v)$. Hasil pengamatan benda coba menunjukkan bahwa komposisi bahan terdapat dalam keadaan sedikit plastis-agak plastis, tidak retak dan tidak bengkok pada saat pengeringan dengan panas matahari dengan susut kering antara $7,5-7,79 \%$, tidak retak dan tidak bengkok setelah dibakar pada suhu $\pm 700^{\circ} \mathrm{C}$ dengan susut bakar antara 1,92-2,94\%.Hasil uji mutu kuat tekan terhadap bata merah dari limbah padat pabrik minyak nabatimemenuhi syarat sesuai standar SNI 15-2094-1991. Kuat tekan terendah terdapat pada contoh Kode B sebesar $63,30 \mathrm{~kg} / \mathrm{cm}^{2}$ dan yang tertinggi pada Kode B1 sebesar 103,30 kg/ $\mathrm{cm}^{2}$. Dengan memperhatikan parameter uji lainnya, produk bata merah dengan perlakuan bahan 70 bagian $\mathrm{SBE}+20$ bagian $\mathrm{TL}+10$ bagian Domato (D) memenuhi standar.

\section{DAFTAR PUSTAKA}

1. Ola AL, dkk.Pengembangan Penelitian Peningkatan Kualitas Minyak Kelapa Kasar Skala IKM. Manado: Komunikasi No. 300 Balai Riset dan Standardisasi Industri Manado; 2008.

2. Mustofa HK. Strategi Pengembangan Industri Kimia Berbasis Kelapa di Indonesia. Bogor: Program of Management and Business, IPB ; 2003.

3. Ketaren S. Pengantar Teknologi Minyak dan Lemak Pangan.Jakarta: UI Press; 1986.

4. Polii FF. Pengaruh Adsorben Arang Aktif dan Bentonit Terhadap Mutu Minyak Kelapa. Manado:Tesis Fakultas Pasca Sarjana Universitas Sam Ratulangi Manado; 2003.

5. Anggraini. R., dkk. "Peningkatan Kualitas Produksi Batu Bata dengan Pemanfaatan Lumpur Lapindo", Malalayang, 2009. "ppm.ub.ac.id/wrp.com/..../retno_anggraeni_ SIAP.pdf. diunduh 27 Mei 2013

6. Badan Standar Nasional, SNI 0449-2010, Lempung dan Felspar, cara uji kimia etode basah". Jakarta. 2010.

7. Badan Standardisasi Indonesia. SNI No. 152094-2000 tentang Mutu dan Cara Uji Bata Merah Pejal. Jakarta: Badan Standardisasi Nasional; 2000.

8. Syarif SR, dkk. Pemanfaatan Limbah Bleaching dari Industri Minyak Nabati sebagai Bahan Bakar. Manado: Komunikasi No.325, Balai Riset dan Standardisasi Industri Manado; 2011.

9. Rohiman, A dan Sri Hudi, "Tinjauan Kekuatan dan Karakteristik Bata Merah yang Terbuat Dari Limbah Lumpur Lapindo, Sidoarjo" Surakarta, 2012, publikasiilmiahums.ac.id/kan,dll/123456789/ 2012, diunduh 27 mei 2013

10. Lasino, dkk, "Penelitian Pemanfaatan Lumpur Sidoarjo Untuk Bata Merah dan Genteng". Jurnal Pemukiman, Vol. 5 No. 3. Hal 132-138 (2010) 